Jurnal Pemberdayaan: Publikasi Hasil Pengabdian kepada Masyarakat

Vol. 4, No. 3, Desember 2020, Hal. 251-258

ISSN:2580-2569; e-ISSN:2656-0542

DOI: https://doi.org/10.12928/jp.v4i3.2445

\title{
Penguatan Pemasaran Batik Ciprat Karya Difabel Melalui Social Media dan Website
}

\author{
Rudi Susanto $^{1}$, Novemy Triyandari Nugroho ${ }^{2}$, Wiji Lestari ${ }^{2}$ \\ Program Studi Teknik Informatika, Fakultas Ilmu Komputer, Universitas Duta Bangsa Surakarta, \\ Jl Bhayangkara No. 55 Tipes, Surakarta, Indonesia ${ }^{1}$ \\ Program Studi Sistem Informasi, Fakultas Ilmu Komputer, Universitas Duta Bangsa Surakarta, Jl \\ Bhayangkara No. 55 Tipes, Surakarta, Indonesia ${ }^{2}$ \\ Email: rudi_susanto@udb.ac.id
}

\begin{abstract}
ABSTRAK
Mitra kegiatan pengabdian masyakat ini adalah KSM Karya Barokah yang bergerak pada usaha produksi batik ciprat karya difabel yang dipasarkan dengan nama batik ciprat pucung. KSM Karya Barokah berada di Desa Pucung, Kecamatan Kismantoro, Kabupaten Wonogiri. Tujuan kegiatan pengabdian masyarakat ini supaya mitra dapat memasarkan produknya melalui social media instagram dan website. Metode pelaksanaan pengabdian masyarakat terdiri dari 1) Persiapan, 2) Pelatihan, 3) Evaluasi dan 4) Penndampingan. Hasil Kegiatan adalah sebagai berikut: 1) KSM Karya Barokah dapat melakukan pemasaran online dengan social media dan website dengan mengelola akun instagram @batik_ciprat_pucung dan website http://batikcipratpucung.com, 2) Pengetahuan mitra terkait pemasaran online dengan social media dan website meningkat sebesar $25.71 \%$. Hasil kegiatan pengabdian masyakat ini menunjukan bahwa kegiatan pengabdian masyarakat memberikan manfaat bagi mitra.
\end{abstract}

Kata kunci: pemasaran, social media, website, batik ciprat.

\section{ABSTRACT}

The partner of this community service activity is KSM Karya Barokah which is engaged in the business of producing ciprat batik karya difabel which marketed under the name batik ciprat pucung. KSM Karya Barokah is located in Pucung Village, Kismantoro District, Wonogiri Regency. The purpose of this community service activity partners can market their products through Instagram and websites. The method of implementing community service consists of 1) Preparation, 2) Training, 3) Evaluation and 4) Mentoring. The results of the activities are as follows: 1) KSM Karya Barokah can do online marketing with social media and websites by managing instagram accounts @batik_ciprat_pucung and website http://batikcipratpucung.com, 2) Knowledge of partners related to online marketing with social media and websites increases by $25.71 \%$. The results of community service activities indicate that community service activities provide benefits for partners.

Keywords: marketing, social media, websites, batik ciprat.

\section{PENDAHULUAN}

Usaha yang dilakukan pemerintah untuk menangani permasalahan ekonomi dan soscial difabel telah dilakukan meskipun belum maksimal (Setyaningsih, 2016). Sejak adanya perubahan data disabilitas dari Indikator Kesehatan menjadi indikator Kesejahteraan Sosial, persoalan disabilitas menjadi masalah sektor sosial. Salah satu upaya pemerintah untuk meminimalisir permasalahan sosial dan ekonomi difabel di masyarakat dengan adanya LBK (Loka Bina Karya) yaitu pusat rehabilitasi bagi para difabel untuk melatih ketrampilan yang berguna bagi dunia kerja (Irwanto dkk, 2010). Meskipun begitu secara umum pemberdayaan untuk penyandang disabilitas (difabel) masih sangat minim. 
Berdasarkan wawancara dengan Kepala Desa Pucung, Kecamatan Kismantoro Kabupaten Wonogiri, Desa Pucung memilik 51 warga penyandang difabel yang tersebar di empat dusun yakni Dusun Jladri, Pucung, Gandring, dan Gupakan. Sejumlah 2 orang menyandang tunarungu, 4 orang gangguan kejiwaan, 17 orang tunawicara, 23 orang tunagrahita, cacat ganda 2 orang, cacat tubuh 2 orang, dan tunanetra 1 orang. Berkaitan dengan pemberdayaan difabel Pemerintah Desa Pucung, Kecamatan Kismantoro, Kabupaten Wonogiri pada bulan Agustus tahun 2018 telah melakukan pelatihan bagi difabel untuk memproduksi batik, seperti pada Gambar 1. Selanjutnya sebagai bentuk partisipasi masyarakat terhadap penyandang difabel di Desa Pucung, dibentuklah wadah yang diberi nama "Kelompok Swadaya Masyarakat (KSM) Karya Barokah" yang anggotanya terdiri dari masyarakat umum dan difabel sejumlah 51 warga. Dalam perkembangannya, KSM Karya Barokah secara bertahap merintis dan mengembangkan kegiatan ekonomi produktif bagi penyandang disabilitas secara berkelompok dengan kegiatan usaha produksi batik ciprat karya difabel.

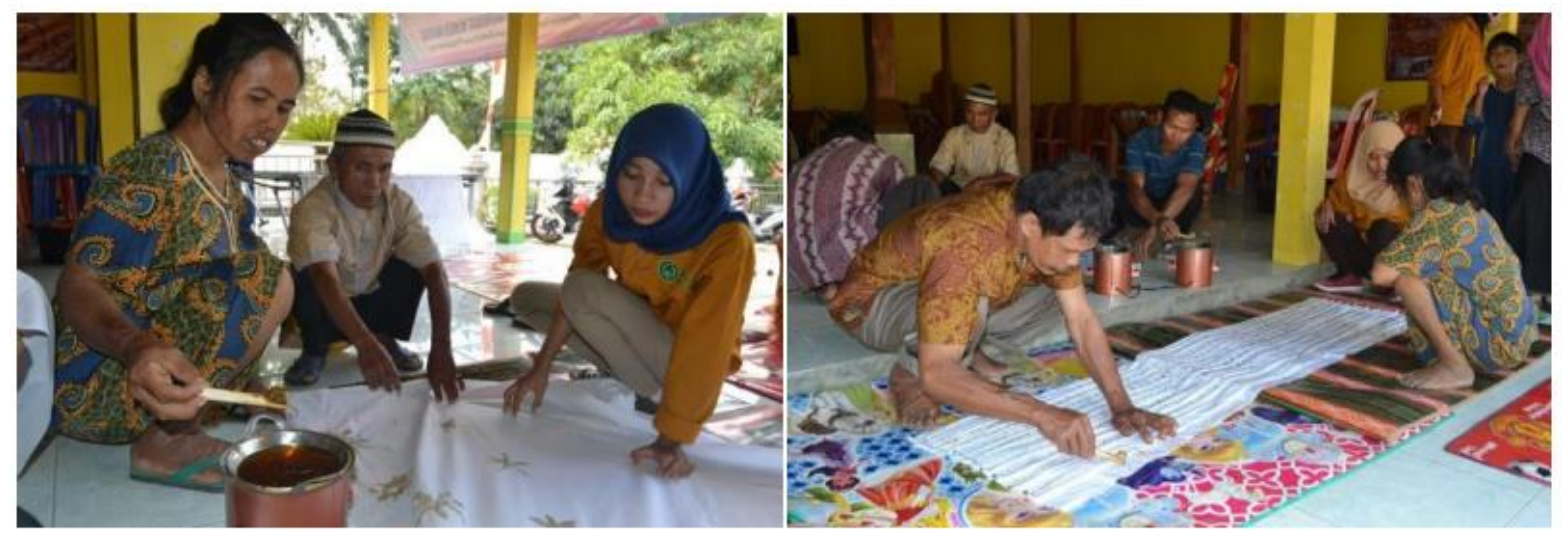

Gambar 1. Pelatihan mebuat batik ciprat bagi difabel Desa Pucung

Berdasarkan wawancara dengan ketua Kelompok Swadaya Masyarakat (KSM) Karya Barokah (Bapak Kateno, S.Sos) selama ini produk batik dipasarkan dengan berbagai hal salah satunya dengan mengikuti pameran-pameran produk potensi desa. Produk batik yang dihasilkan difabel Desa Pucung sejauh ini digunakan, atau dipesan oleh pegawai pemerintah desa, kecamatan dan berbagai instansi lain. Selain itu, pemasaran dilakukan dari mulut ke mulut dan melalui media. Produk batik yang dipasarkan secara umum memiliki harga berkisar antara 130 ribu rupiah sampai 150 ribu rupiah.

Identifikasi permasalah mitra yang dilakukan dengan mendatangi lokasi KSM Karya Barokah di dusun Gandring RT 01/03 Desa Pucung, kemudian melakukan wawancara kepada Bapak Kateno, S.Sos selaku ketua KSM Karya Barokah dan berbagai elemen masyarat seperti kepala Desa Pucung. Berdasarkan hasil wawancara tersebut dapat diindentifikasi permasalah utama produk batik ciprat karya difabel yaitu pada bidang pemasaran antara lain: 1) Pemasaran belum optimal baru melalui pameran, mulut ke mulut dan 2) Media online yang belum terkelola dengan baik. Berkaitan dengan permasalahan tersebut maka KSM Karya Barokah akan diberikan pelatihan dan website pemasaran supaya batik karya difabel dapat dipasarkan berbasis social media dan website.

\section{METODE}

Kegiatan pengandian masyarakat dilakukan kepada pengurus/pendamping KSM Karya Barokah berupa pelatihan terkait dengan pemasaran online berbasis social median dan website. Secara umum tahapan kegiatan terdiri dari persiapan, pelatihan dan pendamping. 
Tahap persiapan terdiri dari persiapan materi, modul dan website yang akan di berikan kepada mitra. Selain itu, tahap persiapan dilakukan komunikasi dengan mitra terkait jadwal dan peralatan yang dibutuhkan saat pelatihan. Tahap pelatihan terdiri dari kegiatan ceramah, workshop dan evaluasi kegiatan pelatihan dengan pre test serta post test. Selain itu, pada tahap pelatihan akan dilakukan serah terima website penjualan kepada mitra. Setelah tapahan tersebut kemudian dilakukan pendampingan terhadap mitra. Secara umum tahapan pelaksanaan disajikan pada Gambar 2.

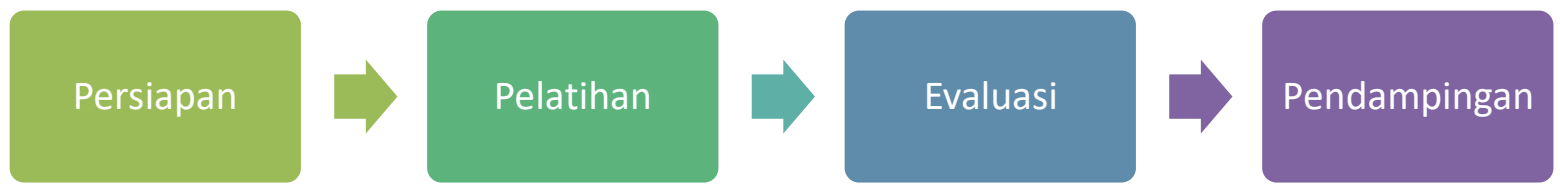

Gambar 2. Tahapan pelaksanaan kegiatan pengabdian

\section{HASIL, PEMBAHASAN, DAN DAMPAK}

Kegiatan persiapan meliputi persiapan materi pelatihan, persiapan modul, pembuatan website dan persiapan peralatan. Materi pelatihan terkait dengan strategi pemasaran dan pemasaran online. Materi ceramah dan diskusi dimaksudkan memberikan pengetahuan wawasan tentang strategi pamasaran dan pemasaran berbasis internet. Modul pelatihan dibutuhkan agar pelatihan dapat berjalan lancar dan efisien. Modul yang dibuat adalah sebagai berikut: 1) Kupas tuntas instagram untuk pemasaran produk berisi tutorial dasar hingga tips pemasaran produk di instagram. dan 2) Manual Prosedur batikcipratpucung.com berisi cara mengelola website berbasis content management system wordpress. Gambar 3 merupakan halaman depan modul pemasaran berbasis social media dan website yang akan diberikan ke mitra.
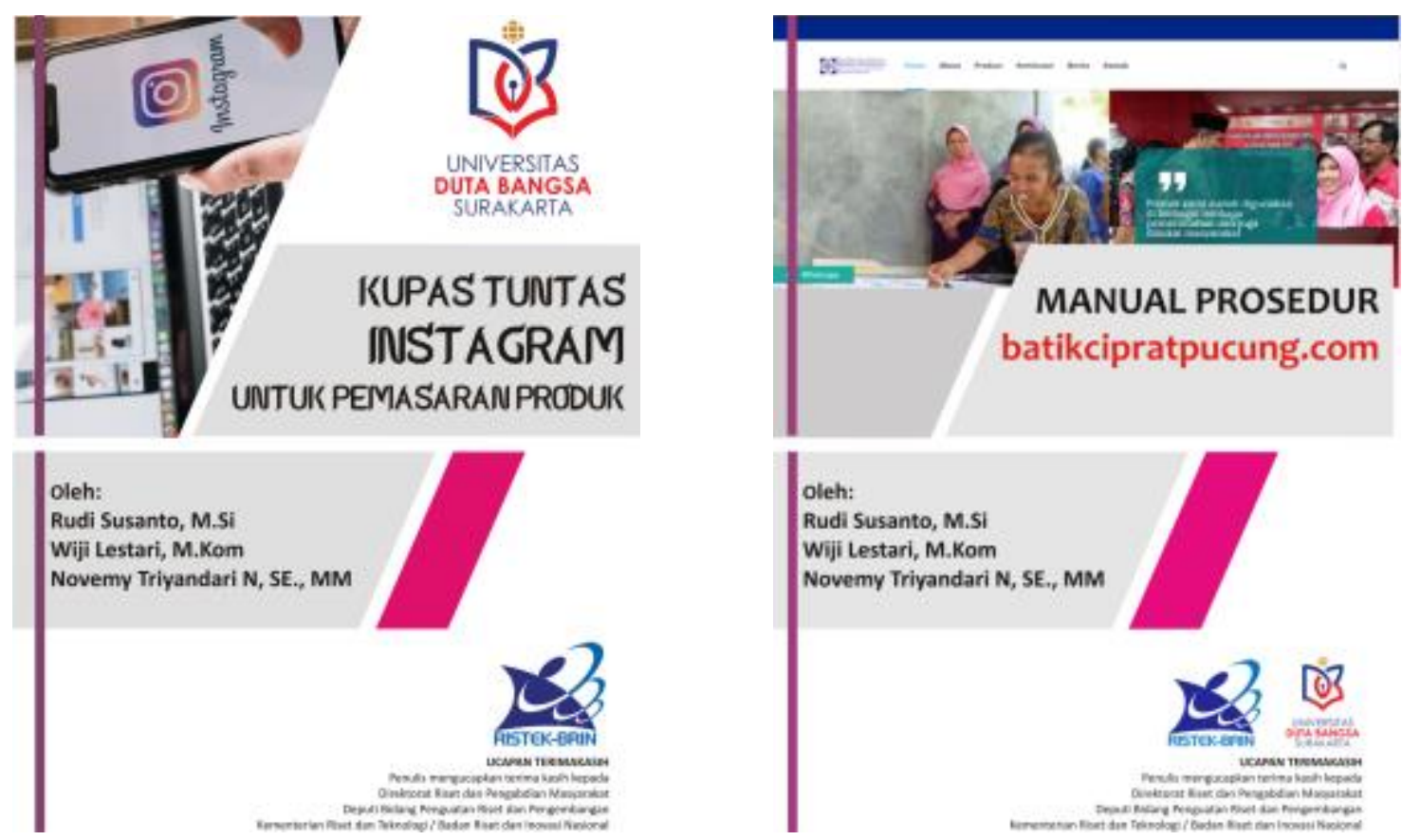

Gambar 3. Modul pemasaran berbasis social media dan website 
Pada tahap persiapan juga dilakukan pembuatan website, alamat website yang akan diberikan ke mitra adalah http://batikcipratpucung.com, seperti tampak pada Gambar 4. Website ini ada digunakan sebagai media promosi dan penjualan yang juga terhubung dengan instagram. Fasilitas website ini terdiri dari halaman profil, halaman produk, halaman kontak dan berbagai fasilitas lain yang memudahkan pengunjung untuk melihat produk dan melakukan pemesanan atau pembelian.

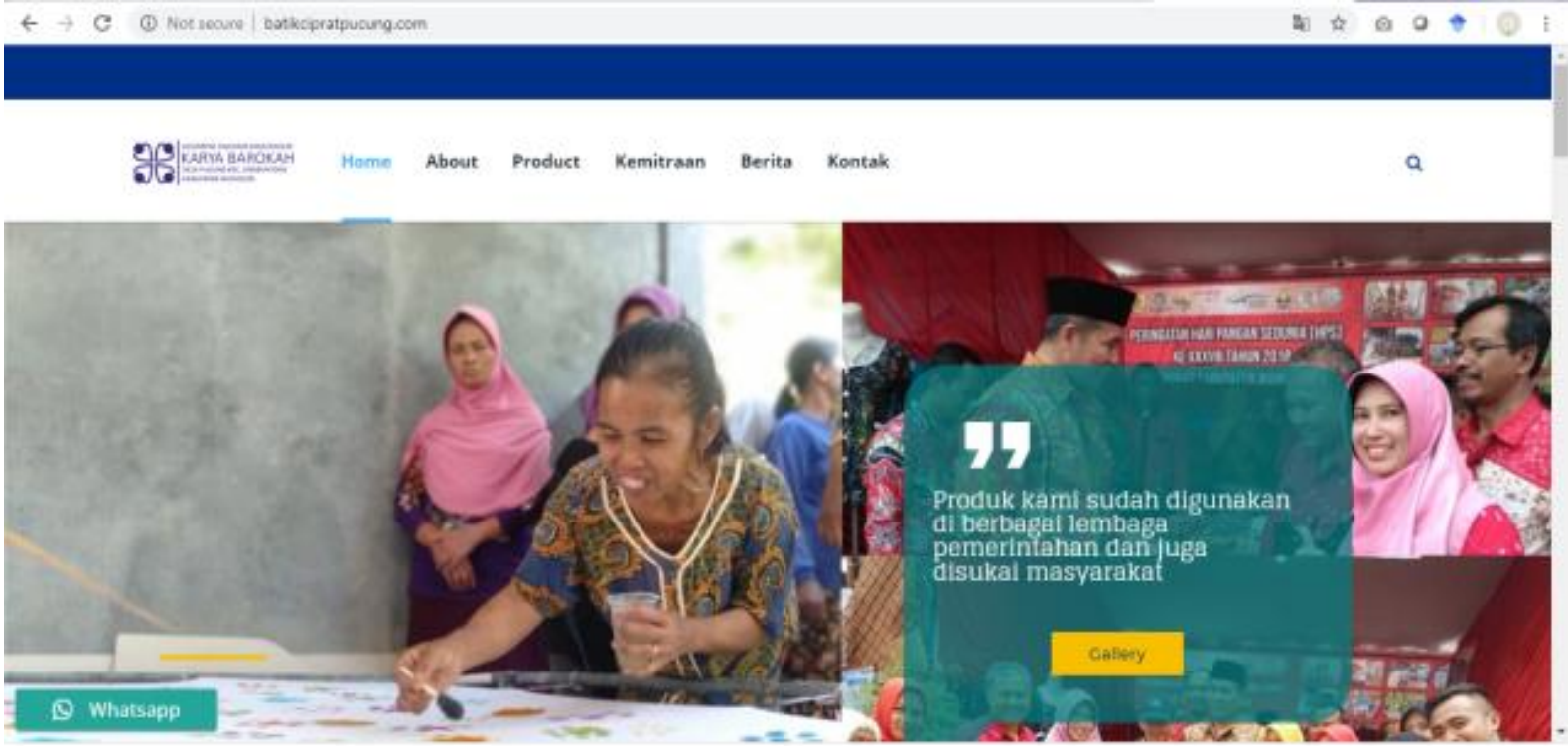

Gambar 4. Halaman depan batikcipratpucung.com

Kegiatan pelatihan dilaksanakan di balai Desa Pucung Kecamatan Kismantoro dengan peserta 7 pendamping KSM karya barokah, seperti tampak pada Gambar 5. Materi yang diberikan terkait dengan strategi marketing, terkait hasil penelitian tim pengabdian yaitu (Nugroho, 2015) bahwa kualitas, harga, dan promosi secara bersama-sama berpengaruh secara signifikan terhadap keputusan pembelian sehingga apabila KSM karya barokah melakukan peningkatan variabel kualitas produk, harga, dan promosi pada batik ciprat karya difabel secara bersama-sama maka keputusan pembelian akan meningkat pula yang akan berdampak pada peningkatan jumlah omzet penjualan.

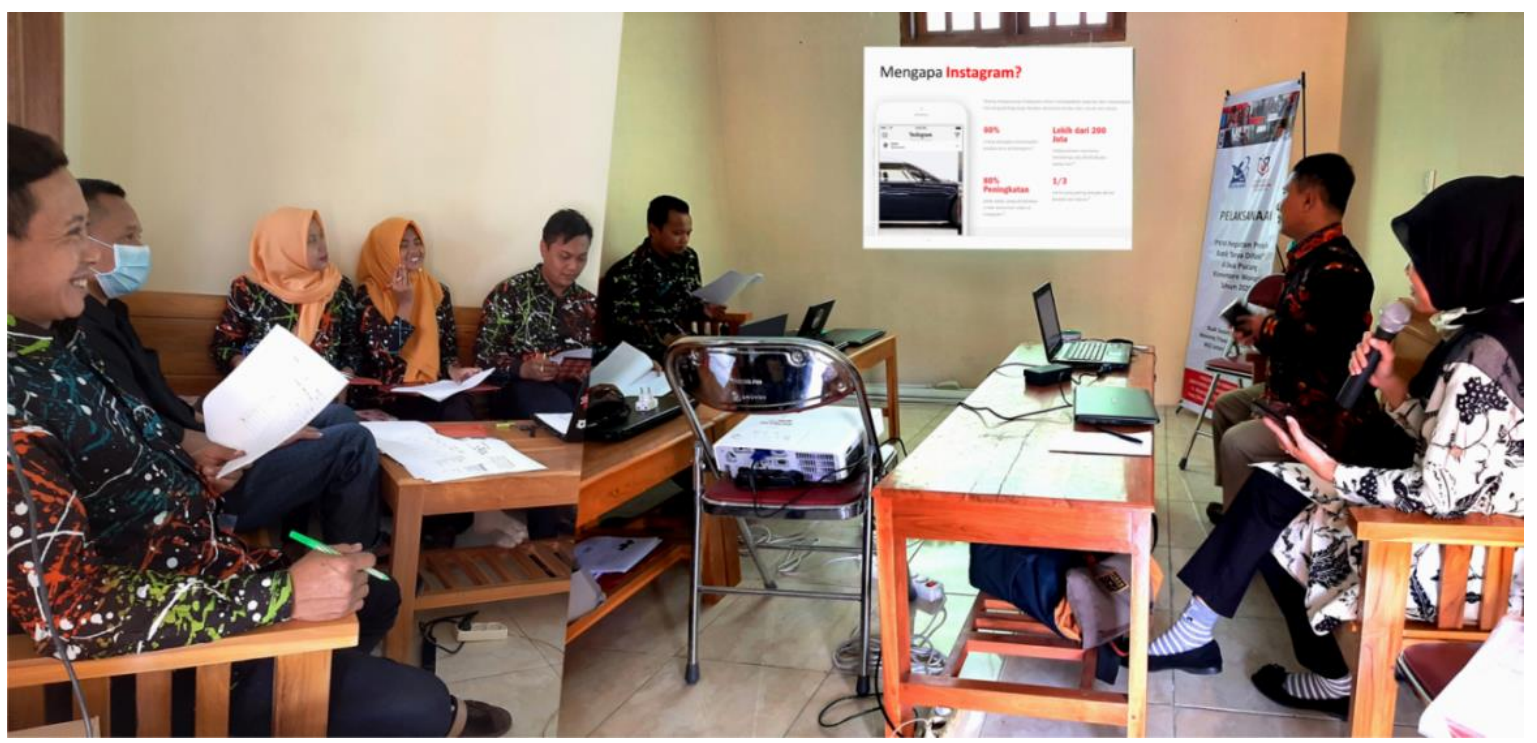

Gambar 5. Pelatihan pemasaran online dengan instagram 
Selain strategi marketing materi difokuskan pada pemasaran secara online mengunakan instagram dan website. Pemilihan media sosial instagram sebagai salah satu sarana dalam melakukan promosi penjualan karena mudah dan efektif (Kurniawan, 2017). Selain itu, instagram lebih menonjolkan gambar dan video sehingga memudahkan pengguna melihat berbagai gambar atau video dengan cepat (Damayanti, 2018). Hal tersebut sesuai dengan krakateristik visual batik ciprat.

Materi pemasaran online dengan website seputar pengelolaan website, terkait posting, page, dan berbagai plugin yang telah di install di website. Workshop dilakukan langsung pada domain http://batikcipratpucung.com yang sebelumnya telah dibuat tim pengabdian pada tahapan persiapan, dashboard website disajikan pada Gambar 6. Nama domain http://batikcipratpucung.com, merupakan hasil usulan dan masukan dari mitra. Pemilihan website dengan mengunakan CMS Wordpress berdasarkan (Soepeno, 2014) bahwa website menggunakan CMS Wordpress memiliki perkembangan yang cukup baik, website memiliki tampilan yang menarik dan mudah digunakan sehingga pengguna tidak bingung dalam pengoperasiannya.

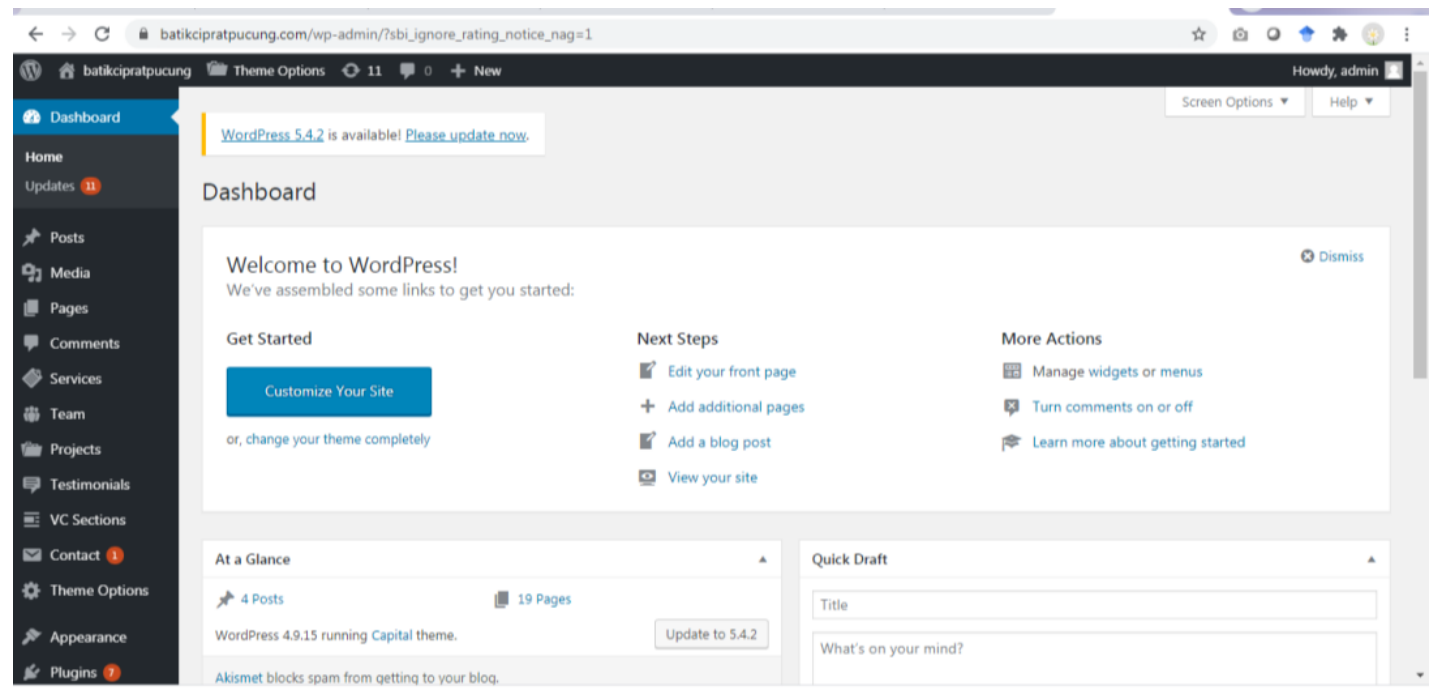

Gambar 6. Tampilan dashboard batikcipratpucung.com

Dari kegiatan pelatihan ini mitra dapat mengelola akun instagram @batik_ciprat_pucung, seperti tampak pada Gambar 7.

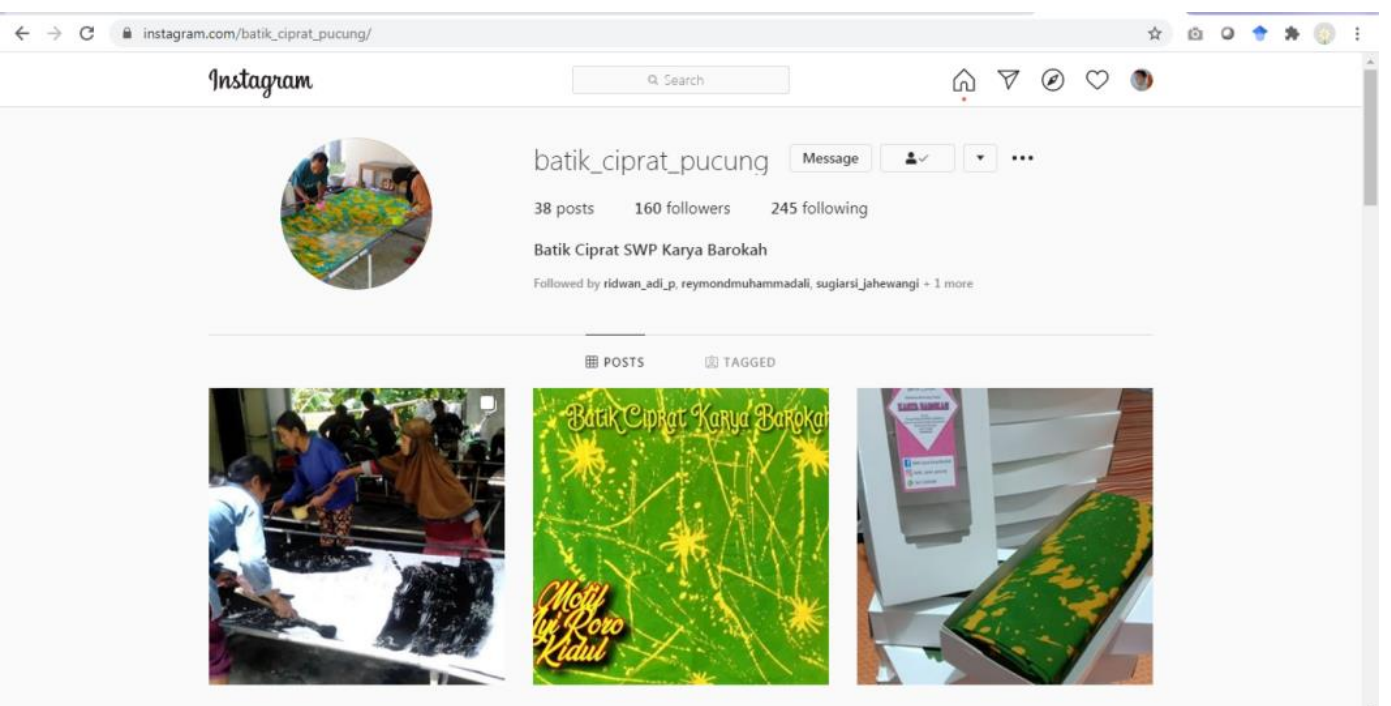

Gambar 7. Akun instagram batik ciprat pucung 
Selain itu, mitra dapat mengelola website http://batikcipratpucung.com khususnya dalam upload produk di https://batikcipratpucung.com/product/ seperti Gambar 8. Berdasarkan diskusi dengan mitra, tim pengabdian kami akan membantu apabila dalam perjalanya mitra mengalami permasalahan baru dalam melakukan pemasaran online melalui social media instagram dan website pada tahap pendampingan, setelah pelaksanaan kegiatan pelatihan.

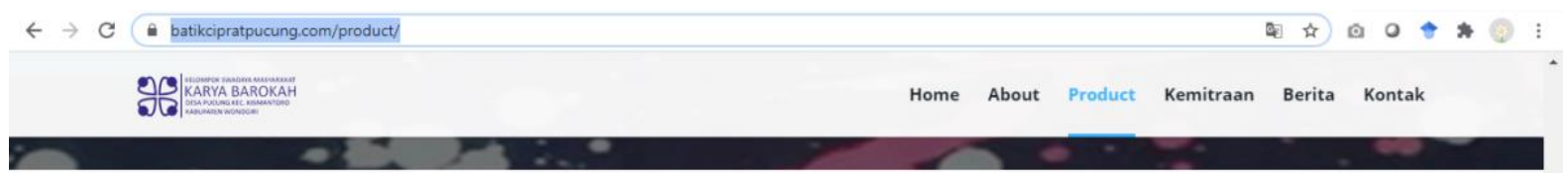

\section{Berikut kumpulan Kain yang sudah di produksi di batikeipratpucung.eom dengan delail seperti pada gambar (Klik gambar untuk memperbesar)}
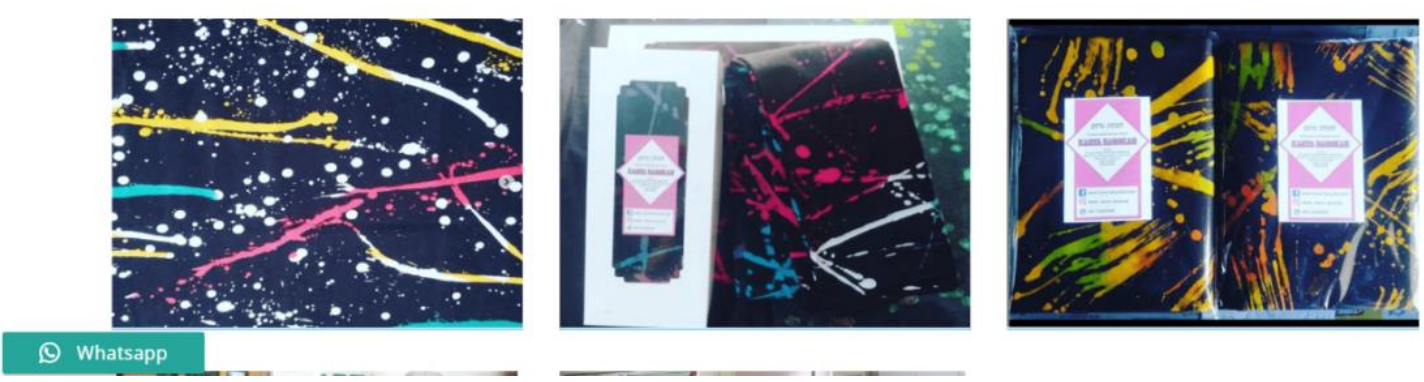

Gambar 8. Produk batik ciprat pucung di upload di website

Evaluasi kegiatan pelatihan dilakukan dengan pre test dan post test terkait dengan social media instagram dan website, disajikan pada Gambar 9. Hasil evaluasi menunjukkan bahwa kegiatan pengabdian masyarakat ini mampu meningkatkan pengetahuan mitra dalam pemasaran online mengunakan social media instagram dan website. Berdasarkan hasil post test, nilai peserta mendapatkan prosentase $100 \%$ benar pada semua soal evaluasi yang diberikan, metode evaluasi sesuai dengan (Dewi, 2017; Susanto, 2018).

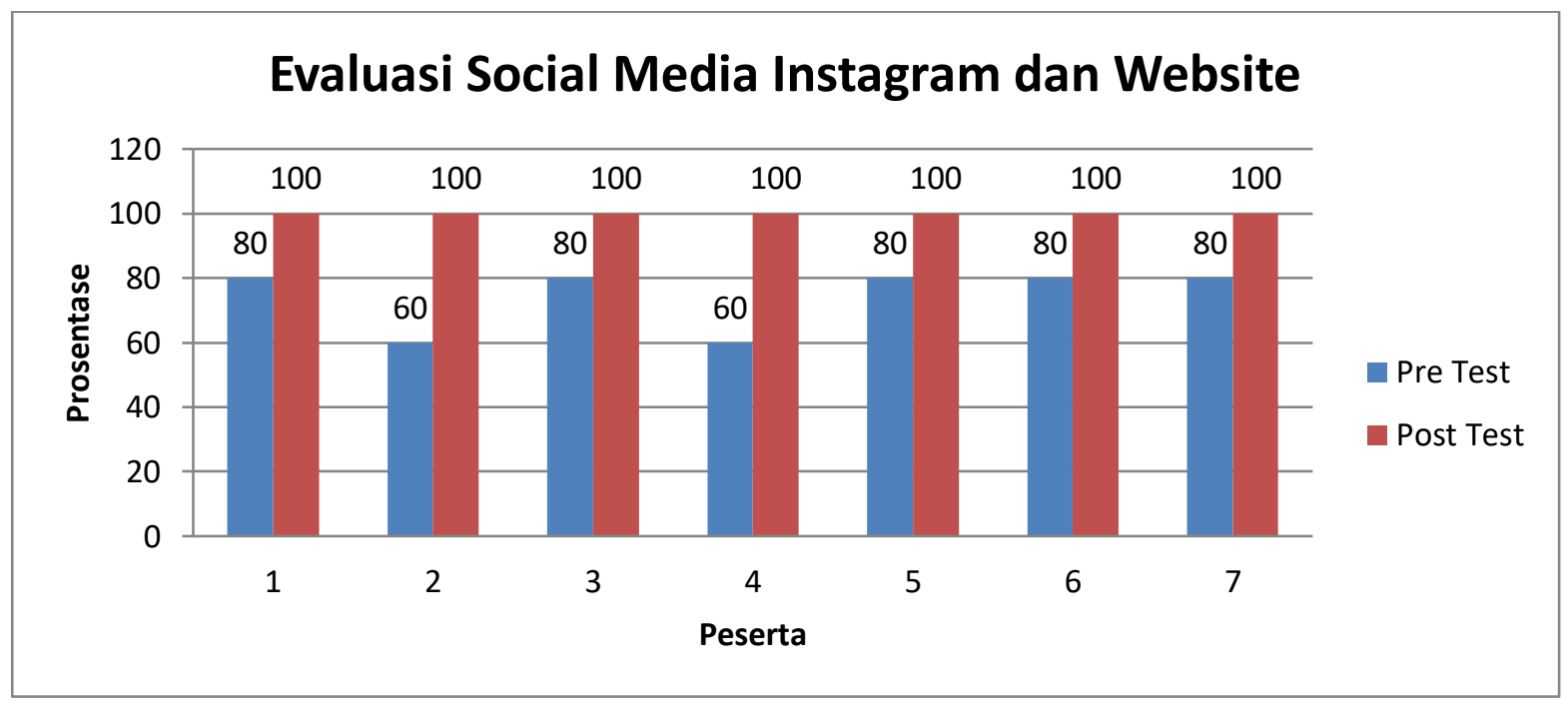

Gambar 9. Hasil evalusi social media instagram dan website. 
Berdasarkan evaluasi pada Gambar 9, peningkatan peningkatan pengetahuan mitra terbesar adalah 40\% (semula $60 \%$ menjadi 100\%) berjumlah 2 peserta. Peningkatan peningkatan pengetahuan mitra terkecil adalah $20 \%$ ( Semula $80 \%$ menjadi $100 \%$ ) berjumlah 5 peserta. Peningkatan pengatahuan mitra rata-rata adalah $25.71 \%$. Dari nilai pre test dan post test dapat diketahui bahwa mitra telah memiliki pengetahuan yang baik terkait pemasaran online mengunakan social media instagram dan website.

\section{SIMPULAN}

Hasil pelaksanan pengabdian masyarakat dengan mitra KSM Karya Barokah adalah sebagai berikut: 1) KSM Karya Barokah dapat melakukan pemasaran online dengan social media dan website dengan mengelola akun instagram @batik_ciprat_pucung dan website http://batikcipratpucung.com., 2) Pengetahuan mitra terkait pemasaran online dengan social media dan website meningkat sebesar $25.71 \%$. Nilai pre test peserta kegiatan yang sudah $60 \%$ ke atas menunjukan bahwa peserta telah memiliki pemahan yang baik terkait online dengan social media dan website.

\section{UCAPAN TERIMAKASIH}

Terima kasih kami sampaikan kepada Direktorat Riset dan Pengabdian Masyarakat Deputi Bidang Penguatan Riset dan Pengembangan Kementerian Riset dan Teknologi / Badan Riset dan Inovasi Nasional yang telah membiayai kegiatan ini sesuai dengan Kontrak Pelaksanaan Program Pengabdian Masyarakat Nomor: 104/SP2H/PPM/DRPM/2020

\section{DAFTAR PUSTAKA}

Damayanti. (2018). PKM Pemanfaatan Media Sosial Instagram Kelompok UKM Kuliner Depok. Prosiding Seminar Nasional Hasil Pengabdian Kepada Masyarakat, 1(1).

Dewi, D. A. L., \& Maslichan. (2017). Upaya Peningkatan Kualitas Produksi dan Manajemen Usaha pada UMKM Genteng dan Batu Bata Di Kabupaten Rembang. Jurnal Pengabdian pada Masyarakat (PENAMAS), 1(1), 34-44.

Irwanto Dkk. (2010). Analisis Situasi Penyandang Disabilitas di Indonesia: Sebuah Desk Review. Jakarta: Pusat Kajian Disabilitas Fakultas Ilmu-Ilmu Sosial dan Politik Universitas Indonesia

Kurniawan, P. (2017). Pemanfaatan Media Sosial Instagram Sebagai Komunikasi Pemasaran Modern Pada Batik Burneh. Kompetensi, 11(2).

Nugroho, N. T. (2015). Analisis Pengaruh Kualitas Produk, Harga Dan Promosi Terhadap Keputusan Pembelian Air Mineral Kemasan (Studi Kasus Desa Tohudan, Colomadu Karanganyar). Jurnal Duta.com, 8(1).

Setyaningsih, R., \& Gutama. (2016). Pengembangan Kemandirian Bagi Kaum Difabel (Studi Kasus pada Peran Paguyuban Sehati dalam Upaya Pengembangan Kemandirian bagi Kaum Difabel di Kabupaten Sukoharjo). Jurnal Sosiologi DILEMA, 31(1).

Susanto, R., dkk. (2018). Usaha Pengeringan Empon-Empon Bahan Obat Herbal Di Kecamatan Kismantoro Kabupaten Wonogiri Provinsi Jawa Tengah. GERVASI: Jurnal Pengabdian kepada Masyarakat, 2(1). 
